\title{
Nitrogen degradation of the limestone-urea mixtures in the rumen of goats
}

\author{
M.A. Harahap, L. K. Nuswantara, E. Pangestu, F. Wahyono, and J. Achmadi* \\ Faculty of Animal and Agricultural Sciences, Diponegoro University, \\ Tembalang Campus, Semarang50275 - Indonesia \\ *Corresponding author: jachmadi@gmail.com
}

Received March 10, 2018; Accepted April 17, 2018

\begin{abstract}
ABSTRAK
Penelitian ditujukan untuk mengkaji kinetika degradasi campuran batu gamping-urea dalam rumen kambing dengan menggunakan teknik kantong nilon. Sampel batu gamping didapatkan dari pegunungan gamping di Kecamatan Pamotan Provinsi Jawa Tengah dan di Kecamatan Wonosari Provinsi Daerah Istimewa Yogyakarta. Campuran dibuat dengan mengombinasikan urea padalevel 25, 50, 75 and 100\% masing-masing dengan dua jenis batu gamping sesuai kandungannya kalsium: L0U100, LP25U75, LP50U50; LP75U25, LW25U75; LW50U50; and LW75U25. Fraksi terlarut, fraksi berpotensial terdegradasi, laju degradasi fraksi berpotensial terdegradasi, dan degradasi efektif dari bahan kering (BK) dan nitrogen $(\mathrm{N})$ yang merupakan kinetika degradasi rumen ditentukan pada masing-masing campuran batu gamping-urea. Hasil penelitian menunjukkan bahwa campuran LP75U25 memiliki degradasi efektif dan laju degradasi fraksi berpotensial terdegradasi $\mathrm{BK}$ dan $\mathrm{N}$ yang paling rendah $(\mathrm{P}<0,05)$ dibandingkan dengan campuran batu gamping-urea lain. Simpulan penelitian ini adalah campuran batu gamping-urea LP75U25 dapat dipertimbangkan sebagai suplemen N lepas lambat dalam rumen.
\end{abstract}

Kata kunci : batu gamping, urea, degradasi, in sacco

\begin{abstract}
This experiment was aimed to study the degradation kinetics of limestone-urea mixtures in the goats rumen using the nylon bag technique. Samples of limestone were obtained from two limestone mountains, Pamotan Subdistrict of Central Java Province and Wonosari Subdistrict of Yogyakarta Province. The mixtures were created by combining urea at levels 25, 50,75and $100 \%$; respectively with two limestones on the basis of their Ca contents: L0U100, LP25U75, LP50U50; LP75U25, LW25U75; LW50U50; and LW75U25. The soluble fraction, potentially degradable fraction, the degradation rate of potentially degradable fraction, and effective degradation of respective dry matter (DM) and nitrogen (N) ruminal degradation kinetics were measured in each mixture. The mixture of LP75U25 had lowest effective and degradation rate of potentially degradable fraction $(\mathrm{P}<0.05)$ respectively for $\mathrm{DM}$ and $\mathrm{N}$ compared with those of other mixtures. In conclusion, the limestone-urea mixture of LP75U25 could be suggested as a dietary supplement of ruminal $\mathrm{N}$ slow release.
\end{abstract}

Keywords: Limestone, urea, degradation, in sacco 


\section{INTRODUCTION}

The use of dietary urea is a strategy related with the improvement of feed cost for ruminant producers. The ammonia from urea could be utilized by rumen microbes as a nitrogen source to synthesize their cell proteins. While urea is hydrolized to ammonia rapidly, the degradation of dietary carbohydrate is more slower in rumen. Delaying the rapid solubility of urea is necessary to synchronize the formation of carbon sceleton and energy from dietary carbohydrate, so that the synthesis of rumen microbes protein could be optimum. Slowing the urea hydrolisis also prevents excessive ruminal ammonia production, thus minimizing ammonia toxicity and ammonia excretion via urine.

The urea-Ca mixture could be a solution for delaying the rate of ammonia release in rumen (Cherdthong et al., 2011a). The hydrogen bonding in the mixture of urea- $\mathrm{CaSO}_{4}$ may cause the slower rate of $\mathrm{NH}_{3}-\mathrm{N}$ formation in rumen (Cherdthong et al., 2011b). The limestone from limestone mountains contain high $\mathrm{Ca}$ and other elements which may be utilized to bind urea. Empirically, the limestone is used commonly in ruminant ration formulation to meet the $\mathrm{Ca}$ requirement of animals (Gastaldello Jr.et al., 2013; Crawford et al., 2014; Guo et al., 2018). A combination between Ca-limestone and urea as a dietary supplement of ruminal $\mathrm{N}$ slow release need to be celucidated.

By using the nylon bag technique, the study was aimed to clarify the ruminal nitrogen $(\mathrm{N})$ degradation kinetics of limestone-urea mixtures. Proper portions of limestone and urea in the combined mixture may be expected as a feed supplement for balanced ruminant ration.

\section{MATERIALS AND METHODS}

\section{Creation of Limestone-urea Mixture and the In sacco Technique}

The study used limestone samples from two sources: (1)Subdistrict of Pamotan, Rembang Regency Province of Central Java (costal region of Java Sea); and (2) Subdistrict of Wonosari, Gunung Kidul Regency, Yogyakarta Province (costal region of Hindia Sea). The sample collection was conducted at July 2016. Pamotan Subdistrict is located at $64^{\circ} 46^{\prime} 15^{\prime \prime} \mathrm{S} 111^{\circ} 27^{\prime} 48^{\prime \prime} \mathrm{E}$ with altitude of $897 \mathrm{~m}$ above sea level with annual rainfall of $1173 \mathrm{~mm}$, annual temperature mean of $23^{\circ} \mathrm{C}$ and $78 \%$ of relative humidity. Wonosari Subdistrict is located at $7^{\circ} 58^{\prime} 34^{\prime \prime} \mathrm{S} 110^{\circ} 35^{\prime} 29^{\prime \prime} \mathrm{E}$ with altitude of $150 \mathrm{~m}$ above sea level with annual rainfall of $2497 \mathrm{~mm}$, annual temperature mean of 27 and $80 \%$ of relative humidity. The $\mathrm{Ca}$ concentrations of limestone from Pamotan subdistrict and Wonosari Subdistrict were 61.93 and $37.94 \%$, respectively.

The limestone samples were collected from three locations of each region. The limestone was dissolved with water $(1: 1 ; \mathrm{w} / \mathrm{w})$ and stirred at $50^{\circ} \mathrm{C}$ for $10 \mathrm{~min}$. The limestone pulp then was mixed with urea to find 4 levels of urea including $100,75,50$ and $25 \%$ of $\mathrm{Ca}$ concentration of limestone. Table 1 shows the portions of

Table 1. Compositions of Limestone-urea Mixture

\begin{tabular}{|c|c|c|c|c|c|}
\hline $\begin{array}{l}\text { Limestone - urea } \\
\text { Mixture }\end{array}$ & Urea & Limestone & $\mathrm{N}^{*}$ & $\mathrm{Ca}^{*}$ & Water \\
\hline & \multicolumn{5}{|c|}{ 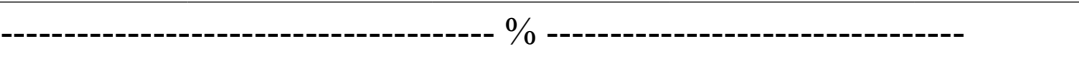 } \\
\hline L0U100 & 100 & 0 & 46.16 & 0 & 0 \\
\hline LP25U75 & 75 & 8 & 41.77 & 4.95 & 17 \\
\hline LP50U50 & 50 & 33 & 24.02 & 20.44 & 17 \\
\hline LP75U25 & 25 & 58 & 10.66 & 35.92 & 17 \\
\hline LW25U75 & 75 & 8 & 39.11 & 3.04 & 17 \\
\hline LW50U50 & 50 & 33 & 26.35 & 12.52 & 17 \\
\hline LW75U25 & 25 & 58 & 13.22 & 22.00 & 17 \\
\hline
\end{tabular}

LP: limestone of Pamotan Subdistrict; LW: Limestone of Wonosari Subdistrict; U: urea.

*Concentrations of $\mathrm{Ca}$ and $\mathrm{N}$ were results of analysis. 
limestone and urea those were tested for their ruminal nitrogen releases. Two female local Ettawah cross bred goats with body weight average of $30 \mathrm{~kg}$ and aged at 36 months were used in this in sacco technique. Animals were fitted with ruminal cannulas with inside diameter of 3 $\mathrm{cm}$. Goats were housed in individual metabolic cages and fed on a diet containing 70\% elephant grass, $10.7 \%$ rice bran, $17 \%$ coconut meal, $1.1 \%$ cassava waste, $1.0 \%$ sugarcane molasses, $0.2 \%$ vitamin-mineral premix. The diet was offered at daily maintenance level and dringking water was available throughout experimental period. The nylon bag technique used nylon bags with dimension of $2 \times 6 \mathrm{~cm}$ and mean pore size of 46 $\mu \mathrm{m}$. Each sample of $3 \mathrm{~g}$ was placed in the bag which was attached with $0.25 \mathrm{~m}$ weighted chain. The bags were suspended in rumen of goats via cannula 3 min after morning feeding. Incubation times were $0.75,1.5,3,6,12,24$, and $48 \mathrm{~h}$. Immediately before and after each incubation time, ruminal $\mathrm{pH}$ values were determined using a portable $\mathrm{pH}$ meter. Three replicates of each sample were tested for each tested limestone-urea mixture and incubation time. There were intervals of $24 \mathrm{~h}$ between each series of incubation time to minimize the effect of previous test. After the time of incubation bags were removed and immersed in ice water for $15 \mathrm{~min}$, the bags were washed with water using a washing machine for $3 \mathrm{~min}$. The bags and sample residues were then dried at $70^{\circ} \mathrm{C}$ for $48 \mathrm{~h}$ before weighing, and sample residues were prepared for chemical analyses.

\section{Chemical and Statistical Analysis}

Sample residues were then determined their nitrogen $(\mathrm{N})$ contents based on kjeldahl method (AOAC, 2005). The ruminal DM and $\mathrm{N}$ disappearances (expressed as \% of the initial amount) were calculated based on the their content of sample residues. The data were then calculated to obtain the kinetics of ruminal DM and $\mathrm{N}$ degradations according to the equation described by Ørskov and McDonald (1979):

$$
\mathrm{P}=a+b\left(-\exp ^{-c t}\right)
$$

where $\mathrm{P}$ is the amount degraded at time $t, a$ is the rapidly soluble fraction, $b$ is the potentially degradable fraction, $c$ is the rate of degradation of fraction $b$ per hour. The parameters of ruminal degradability kinetic were rapidly soluble fraction (fraction $a$ ), potentially degradable fraction (fraction $b$ ), the degradation rate of fraction $b(c)$ for DM and $\mathrm{N}$, respectively. The effective degradation (ED) of DM and $\mathrm{N}$ were also calculated respectively for limestone-urea mixtures using equation: $\mathrm{ED}=\mathrm{a}+[\mathrm{a}+(\mathrm{bc} /(\mathrm{c}+\mathrm{k})]$, where $\mathrm{k}$ is the estimated rate of rumen fractional outflow at $0.03 \mathrm{~h}^{-1}$.

Data of ruminal DM and $\mathrm{N}$ degradation kinetics (fraction $a$, fraction $b, \mathrm{c}$ and ED) were tested using a split-plot ANOVA for incomplete block design, with limestone source and level as main- and sub-plots, respectively. Mean difference of each ruminal degradation kinetics parameters were considered significant at 5\%.

\section{RESULTS AND DISCUSSIONS}

\section{The Ruminal Degradation Kinetics of DM}

Figure 1 illustrates the time course of ruminal DM degradation of the limestone-urea mixtures. The percent of DM disappearances elevated in L50U50, L25U75, and L0U100 of both limestone sourcesat early times of ruminal incubation, but the amount of DM disappearances were more smaller in L75U25.

The fraction a of mixtures were decreased $(\mathrm{P}<0.05)$ by increasing level of limestone for both limestone sources (Table 2). Factors of limestone source and level interacted $(\mathrm{P}<0.05)$ in decreasing the fraction a of mixtures. The limestone level increased $(\mathrm{P}<0.05)$ value of fraction $b$, but the limestone source did not effect significantly the fraction $\mathrm{b}$. The fraction $\mathrm{b}$ was unaffected by the interaction between limestone source and level. The limestone source decreased $(\mathrm{P}<0.05)$ c value of limestone-urea mixtures, but factor of limestone level and the interaction between limestone level and source did not effect on the value of $\mathrm{c}$. The factor of limestone factor did not effect on ED value, though limestone level and interaction between limestone source and level decreased $(\mathrm{P}<0.05) \mathrm{ED}$ value.

\section{The Ruminal Degradation Kinetics of $\mathbf{N}$}

The time course of ruminal $\mathrm{N}$ degradation of limestone-urea mixtures are shown in Figure 1. In similar manner with the degradation of DM, at early times of ruminal incubation the amount of $\mathrm{N}$ disappearances elevated in L50U50, L25U75, and L0U100 of both limestone sources, but the amount of $\mathrm{N}$ disappearances were more smaller in L75U25. The disppearance amount of $\mathrm{N}$ in L0U100 or urea was near to be $100 \%$ during the first hour of ruminal incubation.

There was no significant different between two limestone sources of the mixtures in fraction 

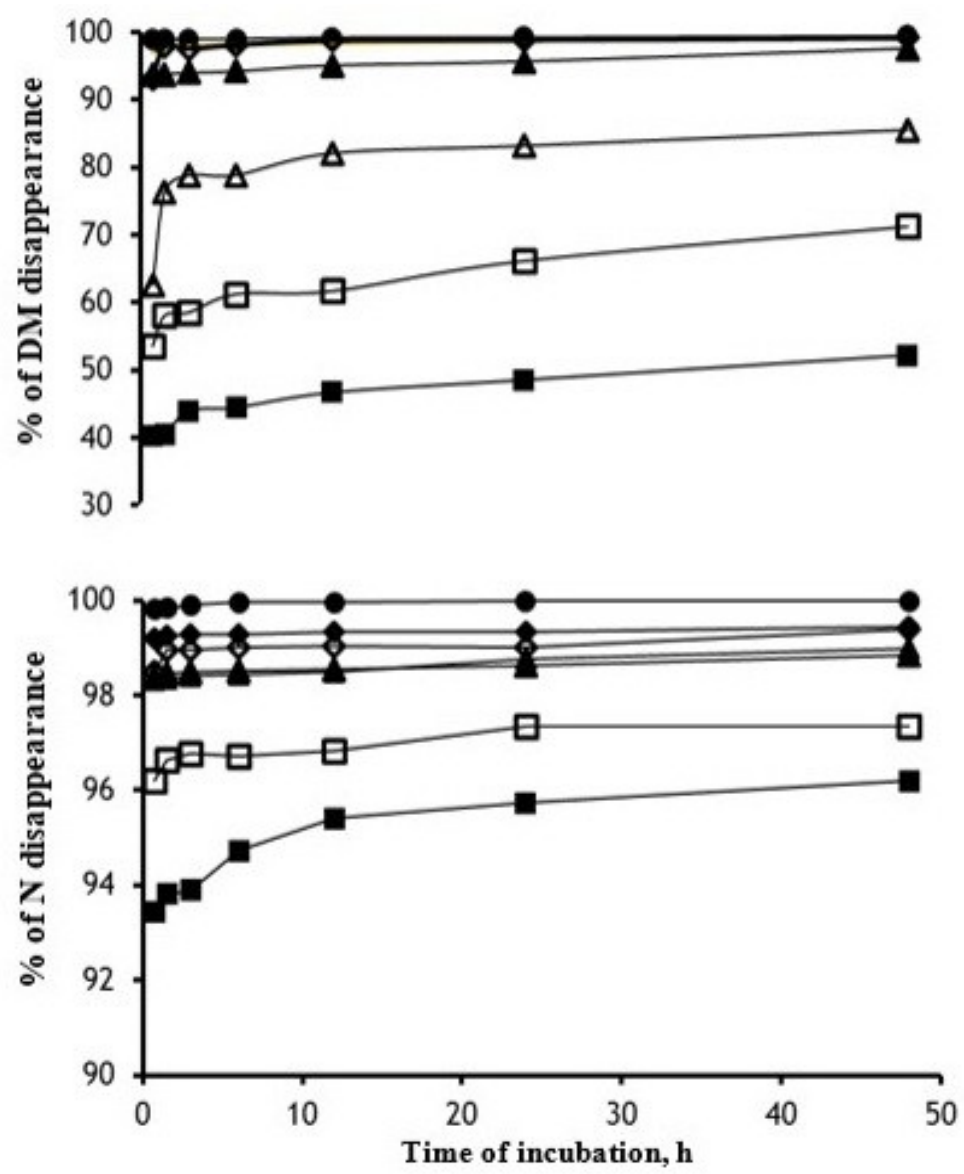

Figure 1. Percent of DM and N Disappearances of L0U100 (9, LP75U25 (ם), LP50U50 (A), LP25U75 $(\diamond)$, LW75U25 $(\square)$, LW50U50 $(\triangle)$, and LW25U75 $(\diamond)$ throughout the Ruminal Incubation Times.

a, but level of limestone decreased $(\mathrm{P}<0.05)$ the fraction a (Table 3$)$. The limestone source and level interacted $(\mathrm{P}<0.05)$ for decreasing percent of fraction $\mathrm{a}$ of the mixtures. The fraction $\mathrm{b}$ was increased $(\mathrm{P}<0.05)$ by limestone level in the mixtures, though limestone source did not effect on the fraction $b$ of mixtures (Table 3). The interaction between limestone source and level did not effect on the fraction $b$. The $c$ value of limestone-urea mixtures from both limestone sources were smaller $(\mathrm{P}<0.05)$ compared with urea. The value of ED's were decreased $(\mathrm{P}<0.05)$ by factors of limestone source and level, and by interaction between factors of limestone source and level (Table 3).

\section{The Ruminal pH}

Figure 2 shows ruminal $\mathrm{pH}$ of goats immediatly before and after each incubation time. Averages of ruminal $\mathrm{pH}$ were 6.91 and 6.89 for before and after incubation times, respectivley. The ruminal ecology, especially ruminal $\mathrm{pH}$, did not change due to immesrion of limestone-urea mixture.

In this experiment, limestone-urea mixtures were created using two sources of limestone mountains with different $\mathrm{Ca}$ content. The levels of urea in limestone-urea mixtures were designed according to the $\mathrm{Ca}$ content of each origin limestone. Thus, the result may be applied in some limestones with different $\mathrm{Ca}$ contents. In general, parameters of ruminal degradation kinetics of respective DM and $\mathrm{N}$ were closely similar in both limetones (Table 2 and 3). This means that limestone may link well the urea through a hydrogen bonding, though the binding mechanism between $\mathrm{Ca}$ of limestone and ammonia of urea remains to be elucidated. Chertdhong et al. (2011b) speculated that the formation of rumen ammonia slow release from $\mathrm{Ca}_{2} \mathrm{SO}_{4}$-urea mixture because of the hydrogen bonding between sulphate group of $\mathrm{Ca}_{2} \mathrm{SO}_{4}$ and amino group of urea substance. The sulphate anions are linked among layers of sulphate and 
Table 2. Parameters of Ruminal DM Degradation Kinetics

\begin{tabular}{lcccc}
\hline \multirow{2}{*}{ Treatments } & \multicolumn{4}{c}{ Degradation kinetics } \\
\cline { 2 - 5 } & Fraction a (\%) & Fraction b $(\%)$ & $\mathrm{c}(\% / \mathrm{h})$ & ED (\%) \\
\hline L0U100 & $98.86^{\mathrm{a}}$ & $0.59^{\mathrm{d}}$ & $5.56^{\mathrm{abc}}$ & $99.17^{\mathrm{a}}$ \\
LP25U75 & $97.64^{\mathrm{a}}$ & $1.59^{\mathrm{cd}}$ & $6.54^{\mathrm{abc}}$ & $98.47^{\mathrm{a}}$ \\
LP50U50 & $93.72^{\mathrm{a}}$ & $3.89^{\mathrm{bc}}$ & $3.40^{\mathrm{bc}}$ & $95.26^{\mathrm{a}}$ \\
LP75U25 & $42.47^{\mathrm{d}}$ & $10.69^{\mathrm{ab}}$ & $2.24^{\mathrm{c}}$ & $46.54^{\mathrm{d}}$ \\
LW25U75 & $96.88^{\mathrm{a}}$ & $2.27^{\mathrm{c}}$ & $9.87^{\mathrm{a}}$ & $98.32^{\mathrm{a}}$ \\
LW50U50 & $94.85^{\mathrm{b}}$ & $10.70^{\mathrm{ab}}$ & $8.67^{\mathrm{ab}}$ & $81.17^{\mathrm{b}}$ \\
LW75U25 & $56.10^{\mathrm{c}}$ & $15.17^{\mathrm{a}}$ & $4.35^{\mathrm{abc}}$ & $63.32^{\mathrm{c}}$ \\
SEM & 4.77 & 1.52 & 0.82 & 4.35 \\
Comparison & & & & $\mathrm{ns}$ \\
Limestone sources & $\mathrm{ns}$ & $\mathrm{ns}$ & $*$ & $*$ \\
Limestone levels & $*$ & $*$ & $\mathrm{~ns}$ & $*$ \\
Interaction & $*$ & $\mathrm{~ns}$ & $\mathrm{~ns}$ & \\
\hline
\end{tabular}

$* \mathrm{P}<0.05$; ns: non significance

Table 3. Parameters of Ruminal N Degradation Kinetics

\begin{tabular}{lcccc}
\hline \multirow{2}{*}{ Treatments } & \multicolumn{4}{c}{ Degradation kinetics } \\
\cline { 2 - 5 } & Fraction a (\%) & Fraction $\mathrm{b}(\%)$ & $\mathrm{c}(\% / \mathrm{h})$ & ED $(\%)$ \\
\hline L0U100 & $99.86^{\mathrm{a}}$ & $0.11^{\mathrm{c}}$ & $17.70^{\mathrm{a}}$ & $99.95^{\mathrm{a}}$ \\
LP25U75 & $99.24^{\mathrm{ab}}$ & $0.20^{\mathrm{bc}}$ & $3.73^{\mathrm{b}}$ & $99.32^{\mathrm{b}}$ \\
LP50U50 & $98.43^{\mathrm{b}}$ & $0.40^{\mathrm{bc}}$ & $2.80^{\mathrm{b}}$ & $98.57^{\mathrm{c}}$ \\
LP75U25 & $93.70^{\mathrm{d}}$ & $2.58^{\mathrm{a}}$ & $6.50^{\mathrm{b}}$ & $95.17^{\mathrm{e}}$ \\
LW25U75 & $98.82^{\mathrm{ab}}$ & $0.56^{\mathrm{bc}}$ & $3.97^{\mathrm{b}}$ & $99.07^{\mathrm{b}}$ \\
LW50U50 & $98.29^{\mathrm{b}}$ & $0.69^{\mathrm{bc}}$ & $5.16^{\mathrm{b}}$ & $98.61^{\mathrm{c}}$ \\
LW75U25 & $96.39^{\mathrm{c}}$ & $1.02^{\mathrm{b}}$ & $6.76^{\mathrm{b}}$ & $97.03^{\mathrm{d}}$ \\
SEM & 0.45 & 0.21 & 1.33 & 0.34 \\
Comparison & & & & $*$ \\
Limestone sources & $\mathrm{ns}$ & $\mathrm{ns}$ & $\mathrm{ns}$ & $*$ \\
Limestone levels & $*$ & $*$ & $\mathrm{~ns}$ & $*$ \\
Interaction & $*$ & $\mathrm{~ns}$ & $\mathrm{~ns}$ & $*$ \\
\hline
\end{tabular}

$* \mathrm{P}<0.05$; ns: non significance

chelate by urea group. The urea molecules participate in the hydrogen bonding both as donor and acceptor. The water molecules are also added and create an additional hidrogen bond to sulphates. One water molecule then forms hydrogen bonds to $\mathrm{CO}$ group of urea.The 


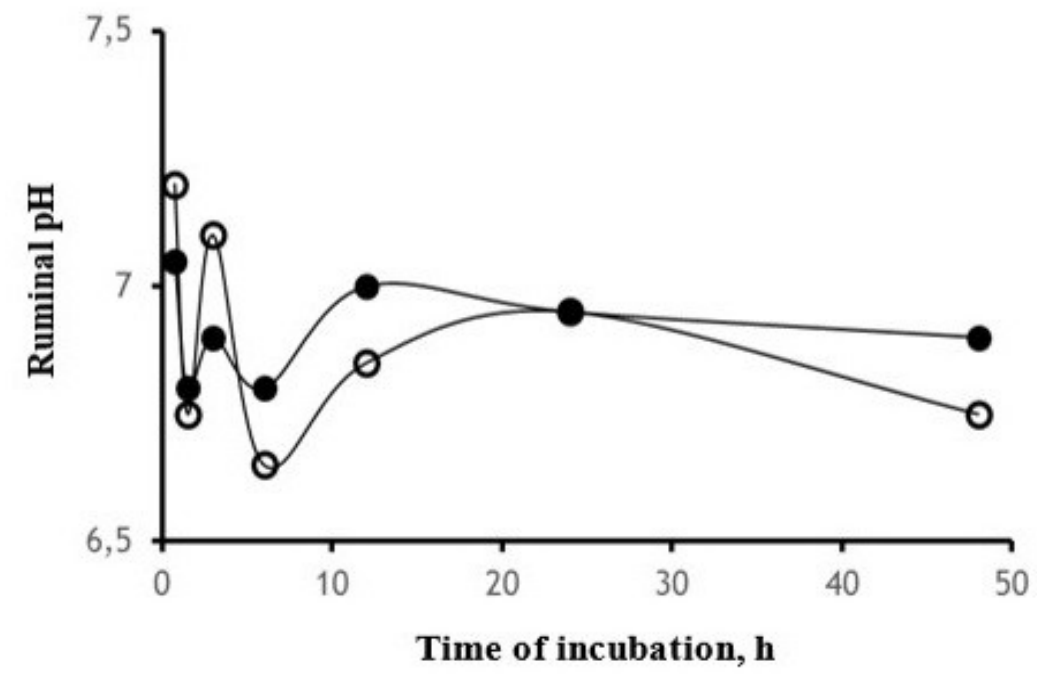

Figure 2. Ruminal pH Before ( 9 and After ( 9 Each Incubation Time.

discussionis focused on determination of the limestone-urea mixture in favour of delaying its ruminal nitrogen release by using data of ruminal $\mathrm{DM}$ and $\mathrm{N}$ degradation kinetics.

A good source of dietary protein should have a low value of ED, thus providing one part of degraded protein which is used for microbes and other part of rumen by pass protein which is supplied to the host animal (Kamalak et al., 2005; Promkot et al., 2007; Foster et al., 2012). A lower ruminal degradability may contribute to slow the nitrogen release from limestone-mixture in rumen, although the mixture is only intended to supply the rumen microbe protein synthesis. Table 2 and 3 shows that increasing level of limestone in the mixture decrased $(\mathrm{P}<0.05)$ ED of DM and $\mathrm{N}$ in both limestones. The decreased soluble fraction and increased potentially degradable fraction favoured to these lower ED's when limestone level were increased. Decreasing the rate constant of fraction $b$ disappearence also contributed to lowering ED when limestone was increased up to $75 \%$ in the mixture.

Information about the binding capacity of limestone to urea is obscure at the present time, therefore no comparison with any result of previous study can be made. The degradadability (ED) and degradation rate (c) of respective $\mathrm{N}$ and DM in L0U100 were highest among mixtures (Table 2 and 3). Suhada et al. (2016) found that $95 \%$ of urea was rapidly hydrolized in rumen within first hour after incubation. In comparison with other mixtures, the LP75U25 could be considered as the best mixture of limestone-urea, because the ED value was lowest and c values was greatest, respectively for DM and N (Table 2 and 3). Chertdhong et al. (2011a) reported that mixtures of $\mathrm{C}_{\mathrm{a}} \mathrm{Cl}_{2}+$ urea or $\mathrm{CaSO}_{4}+$ urea in combination with cassava chip or corn meal decrease in vitro ruminal ammonia and increase ruminal volatile fatty acids compared with urea in combination with cassava chip or corn meal.

\section{CONCLUSION}

The combination of $35.92 \%$ Ca-limestone and $10.66 \% \mathrm{~N}$-urea in a mixture could favour to create the supplement of limestone based $\mathrm{N}$ slow release, although its application for balancing the ruminant feed requires further study.

\section{ACKNOWLEDGMENTS}

This research project was funded by Pendidikan Master menuju Doktor untuk Sarjana Unggul (PMDSU) Scholarship Batch II 2015, Ministry of Research, Technology and Higher Education, Republic of Indonesia with contract No. 325/SP2H/LT/DRPM/IX/2016 dated 8 September 2016.

\section{REFERENCES}

AOAC. 2005. Official Methods of Analysis of AOAC International. 18th ed. Assoc. Off. Anal. Chem., Arlington 
Cherdthong, A., M. Wanapat, and C. Wachirapakorn. 2011a. Influence of ureacalcium mixtures asrumen slow-release feed on in vitro fermentation using a gas production technique. Arch. Anim. Nutr. 65: 242-254.

Cherdthong, A., M. Wanapat, and C. Wachirapakorn. 2011b. Influence of urea calcium mixture supplementation on ruminal fermentation characteristics of beef cattle fed on concentrates containing high levels of cassava chips and rice straw. Anim. Feed Sci. Technol. 163: 43-51.

Crawford, G. I., C. D. Keeler, J. J. Wagner, C. R. Krehbiel, G. E. Erickson, M. B. Crombie, and G. A. Nunnery. 2014. Effects of calcium magnesium carbonate and roughage level on feedlot performance, ruminal metabolism, and site and extent of digestion in steers fed high-grain diets. J. Anim. Sci. 86: 29983013.

Foster, J.L., G.C. Lamb, B.L. Tillman, J.J. Marois, D.L. Wright, M.K. Maddox. 2012. In sacco degradation kinetics of fresh and field-cured peanut (Arachis hypogaea L.) forage harvested at different maturities. Anim. Feed Sci. Technol. 171: 52-59.

Gastaldello Jr., A. L., A.V. Piresa, I. Susina, C.Q. Mendesb, M.A.A. Queirozc,R.C. Amarala, R.S. Gentila, E.M. Ferreirad, G.B. Mourãoa, and M.L. Eastridge. 2013. Limestone with different particle size and sodiumbicarbonate to feedlot lambs fed high grain diets with orwithout monensin. Small Rum. Res. 144:80-85.

Guo, C., H. Li, D. Sun, J. Liu and S. Mao. 2018. Effects of abomasal supplementation of quercetin on performance, inflammatory cytokines, and matrix metalloproteinase genes expression ingoats fed a high-grain diet. Livestock Sci. 209:20-24.

Kamalak, A., O. Canbolat, Y. Gurbuz and O. Ozay. 2005. In situ ruminal dry matter and crude protein degradability of plant- and animal-derived protein sources in Southern Turkey. Small. Rum. Res. 58: 135-141.

Ørskov, E. R. and I. McDonald. 1979. The estimation of protein degradabality in the rumen from incubation measurements weight according to rate of passage. J. Agric. Sci. 92 : 499-503.

Promkot, C., M. Wanapat and P. Rowlinson. 2007. Estimation of ruminal degradation and intestinal digestion of tropical protein resources using the nylon bag technique and the three-step in vitroprocedure in dairy cattle on rice straw diets. Asian-Aust. J. Anim. Sci. 12: 1849-1857.

Suhada, A. T., L. K. Nuswantara, E. Pangestu, F. Wahyono and J. Achmadi. 2016. Effect of synchronization of carbohydrate and protein supply in the sugarcane bagasse based diet on microbial protein synthesis in sheep. J. Indonesian Trop. Anim. Agric. 41:135-144. 